\title{
Outcomes of limited proximal aortic replacement for type A aortic dissection in octogenarians: What does "age" mean?
}

\author{
Jean Bachet, MD
}

\footnotetext{
From Association pour le Development des Techniques en chirurgie cardiaque et cardiologie (ADETEC), Suresnes, France.

Disclosures: Author has nothing to disclose with regard to commercial support.

Received for publication March 23, 2016; accepted for publication March 24, 2016; available ahead of print May 24, 2016.

Address for reprints: Jean Bachet, MD, ADETEC, 1 place Marcel Legras, Suresnes, France 92150 (E-mail: jean. bachet@yahoo.fr).

J Thorac Cardiovasc Surg 2016;152:447

$0022-5223 / \$ 36.00$

Copyright (C) 2016 by The American Association for Thoracic Surgery

http://dx.doi.org/10.1016/j.jtcvs.2016.03.070
}

In their article in this issue of the Journal, Kondoh and colleagues ${ }^{1}$ report the results in a large cohort of octogenarians undergoing emergency operation for acute type A aortic dissection. The authors address an important question that might become increasingly frequent and troublesome within the surgical community and the healthcare system: At what age should we stop performing risky and difficult emergency procedures with uncertain outcomes?

The authors obtained very satisfactory results that are in line with what is generally obtained and published in younger cohorts of patients. They conclude that those satisfactory results are attributed mainly to their technique of vessel replacement, limited mostly to the ascending aorta or the hemi-arch.

\section{Is This Really So?}

One may disagree somewhat with the authors' opinion that their good surgical results were attributed to this "limited replacement of the aorta." Indeed, we may observe that the selection of patients played an important role in their decision for surgery. Approximately $10 \%$ of the patients died before the procedure could be considered and, in all of the patients who underwent surgery, the operation was performed only after the patient was in good enough condition to sign a written consent. Obviously, this is not the usual pattern of most reported experiences.

It is also noteworthy that the "limited replacement" used by the authors in their octogenarian patients is the technique used by most groups worldwide in the large majority of patients regardless of age, except in patients with connective tissue disease or with a severely dilated or jeopardized aortic arch. The few reported experiences of systematic total arch replacement remain the exception.

But the most important and unresolved question is: What does age mean? Age does not provide an objective criterion of any individual's health condition. Using age (eg, 80 years) as a cutoff seems rather artificial and questionable. Indeed,

\section{References} 2010;210:901-8.

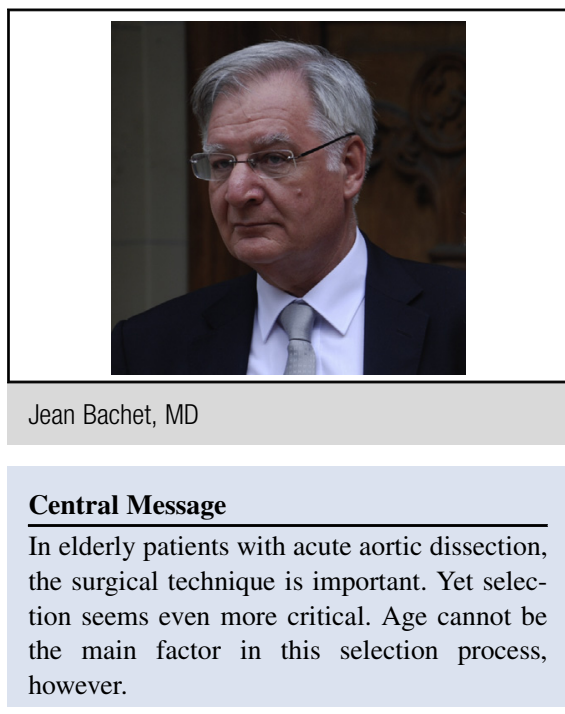

See Article page 439.

in most individuals, is there any obvious difference in health condition between 79 years and 80 years? Moreover, daily observation shows many octogenarians in perfect shape, autonomous, and with a good social, intellectual, and physical life, whereas other, much younger individuals without any defined disease are mentally and physically impaired. Are those 2 types equivalent?

It seems that other criteria for selection should be used. In this regard, in addition to the usual surgical scores, the indices of frailty developed mostly by geriatricians could be of some interest and could better define those individuals actually at major risk. ${ }^{2}$ Obviously, some of the elements included in those indices are difficult to assess in a patient referred for emergency surgery for acute dissection. Yet a rapid but well-focused conversation with the patient (if possible) and/or his or her relatives could perhaps give some good idea of his or her past, usual physical status, and living conditions and could be subject to a more objective and realistic scoring than age alone. Unfortunately, however, it seems that to date, those indices and frailty scores have not been widely adopted by the cardiovascular surgical community.

1. Kondoh. Outcomes of limited proximal aortic replacement for type A aortic dissection in octogenarians. J Thorac Cardiovasc Surg. 2016;152:439-46.

2. Makary MA, Segev DL, Pronovost PJ, Syin D, Bandeen-Roche K, Patel P, et al Frailty as a predictor of surgical outcomes in older patients. J Am Coll Surg. 